Article

\title{
Soil and Groundwater Investigation for Sustainable Agricultural Development: A Case Study from Brunei Darussalam
}

\author{
Siti Lieyana Azffri 1,*, Azimatul Azaman ${ }^{1}$, Rahayu Sukmaria Sukri ${ }^{2}$, Salwana Md Jaafar ${ }^{2}$, Md Faizan Ibrahim ${ }^{3}$, \\ Mario Schirmer ${ }^{4,5}$ and Stefan Herwig Gödeke ${ }^{1, *(D)}$
}

check for

updates

Citation: Azffri, S.L.; Azaman, A.; Sukri, R.S.; Jaafar, S.M.; Ibrahim, M.F.; Schirmer, M.; Gödeke, S.H. Soil and Groundwater Investigation for Sustainable Agricultural Development: A Case Study from Brunei Darussalam. Sustainability 2022, 14, 1388. https://doi.org/ $10.3390 /$ su14031388

Academic Editor: Lucio Di Matteo

Received: 8 December 2021

Accepted: 9 January 2022

Published: 26 January 2022

Publisher's Note: MDPI stays neutral with regard to jurisdictional claims in published maps and institutional affiliations.

Copyright: (c) 2022 by the authors. Licensee MDPI, Basel, Switzerland. This article is an open access article distributed under the terms and conditions of the Creative Commons Attribution (CC BY) license (https:// creativecommons.org/licenses/by/ $4.0 /)$.
1 Geoscience Programme, Faculty of Science, Universiti Brunei Darussalam, Gadong BE1410, Brunei; 21m2809@ubd.edu.bn

2 Institute for Biodiversity and Environmental Research, Universiti Brunei Darussalam, Gadong BE1410, Brunei; rahayu.sukri@ubd.edu.bn (R.S.S.); salwana.jaafar@ubd.edu.bn (S.M.J.)

3 Department of Agriculture and Agrifood, Ministry of Primary Resources and Tourism, Berakas BB3513, Brunei; faizan.ibrahim@agriculture.gov.bn

4 Eawag, Swiss Federal Institute of Aquatic Science and Technology, 8600 Dübendorf, Switzerland; mario.schirmer@eawag.ch

5 Centre of Hydrogeology and Geothermics (CHYN), University of Neuchâtel, 2000 Neuchâtel, Switzerland

* Correspondence: 19h8520@ubd.edu.bn (S.L.A.); stefan.godeke@ubd.edu.bn (S.H.G.)

\begin{abstract}
Brunei has made significant progress in agricultural development over the past four decades. However, crop production, such as rice, is still insufficient to meet the demands of the growing population, mainly due to the scarcity of water resources, acidic soils, and advancing environmental deterioration. This study conducted soil and groundwater investigations at three selected rice cultivation sites in Brunei Darussalam. The geoelectrical resistivity method using the vertical electrical sounding (VES) technique delineated subsurface stratigraphy with resistivities ranging from 1 to $180 \Omega \mathrm{m}$ in the investigated area. A potential aquifer zone was inferred in one of the surveyed areas with resistivities ranging from 10 to $150 \Omega \mathrm{m}$ at depths of about 40 to $60 \mathrm{~m}$ below ground level. Groundwater levels were also shallower in irrigated sites compared to nonirrigated sites. Groundwater physicochemical properties revealed high alkalinity and mineralisation, as evident from high magnesium, bicarbonate, ammoniacal nitrogen, and iron, as well as $\mathrm{pH}$ values in the water samples, believed to be the effects of leaching of salt ions into the shallow aquifer through infiltration recharge. In addition, soil physicochemical properties showed that the soils near a pumping well were more acidic, had lower moisture, and total nutrients, likely due to the effects of groundwater pumping. Our results demonstrate that future irrigation activities need to consider local aquifer characteristics, groundwater flow paths, and nutrient transport to ensure sustainable development in agricultural areas.
\end{abstract}

Keywords: groundwater; resistivity; irrigation; salinity; soil quality; Brunei

\section{Introduction}

Water is key for agricultural production. Globally, the agricultural sector is responsible for more than $70 \%$ of water withdrawal from rivers, lakes, and groundwater, significantly for irrigation purposes [1]. Groundwater, in particular, is a vital source of freshwater, especially when surface water sources have been depleted or rainfall is insufficient. Countries such as the USA, China, India, Iran, and Pakistan account for more than $60 \%$ of groundwater abstracted each year worldwide [2]. In general, groundwater can provide a renewable source of water that farmers can use to the extent permitted by its quality and quantity. However, in many food-producing regions, excessive groundwater abstraction and climate change have led to a significant decline in groundwater levels, depletion of 
aquifers, and deterioration of groundwater quality $[3,4]$. Thus, the sustainable management of groundwater resources for irrigation is vital.

The growth of many agricultural regions has been accompanied by intensive use of artificial fertilisers and irrigation practices, which can significantly influence soil and groundwater quality [5]. Studies show that irrigation practices can enrich dissolved organic matter in shallow aquifers and transport ions and nutrients from the soil into the aquifer, altering groundwater chemistry [6,7]. Furthermore, irrigation practices can lead to groundwater mounding, which, if not properly managed, can lead to environmental problems $[8,9]$. Irrigation can also lead to higher groundwater levels in irrigated fields and lower groundwater levels in non-irrigated fields, stressing the importance of groundwater level monitoring for sustainable irrigation practices [10]. Other studies show that the depth of the water table, groundwater flow, and drainage conditions affect the salt accumulation process in both soil and water [11,12]. High water salinity will negatively impact soil quality and eventually disrupt crop growth and yield $[13,14]$. Therefore, assessing the impacts of anthropogenic activities on soil and groundwater play a crucial part in establishing long-term resource management plans in agricultural areas.

Geoelectrical resistivity methods have been widely used to detect groundwater zones [15,16], monitor groundwater remediation campaigns [17], and investigate aquifer hydraulic conductivities [18]. In addition, correlations have been made between resistivity and electrical conductivity of groundwater for irrigation purposes [19]. Furthermore, variations in resistivities are common across various rock types and characteristics, and they are influenced by factors such as porosity, water saturation, and dissolved salt content $[20,21]$. Most recently, groundwater exploration using the Electrical Resistivity Tomography (ERT) technique was conducted at the Labi agricultural site, Brunei [22]. The study detected moderate groundwater potential for withdrawal and distribution in the investigated area for irrigation purposes.

Irrigation in the tropical Brunei Darussalam relies heavily on surface water resources, which are under increasing strain due to the growing population and emerging contaminants. Groundwater resources are being considered to supplement these irrigation needs, but the availability and suitability of this resource in agricultural areas are not well studied. Therefore, this study conducted the Vertical Electrical Sounding (VES) technique in selected rice cultivation sites in Brunei Darussalam to delineate potential aquifer zones for groundwater irrigation use. Groundwater was sampled from existing wells to investigate its suitability for irrigation purposes. Soils in paddy fields were sampled and analysed to assess the effects of the nearby groundwater pumping on the soil quality.

\section{Materials and Methods}

\subsection{Study Area}

\subsubsection{Location and Climate}

Brunei Darussalam is located in Southeast Asia, on the northwest coast of Borneo Island (Figure 1). The country is divided into four main districts, having an area of $5770 \mathrm{~km}^{2}$. The study area lies in the most populous district, Brunei-Muara District, with an area of $571 \mathrm{~km}^{2}$. Three rice cultivation sites were chosen as survey locations, namely site-1, site-2, and site- 3 (Figure 2a). In addition, groundwater and soil sampling were conducted at site-2. This site was chosen due to an existing groundwater well on which a pumping test was recently completed (Figure 2b). 


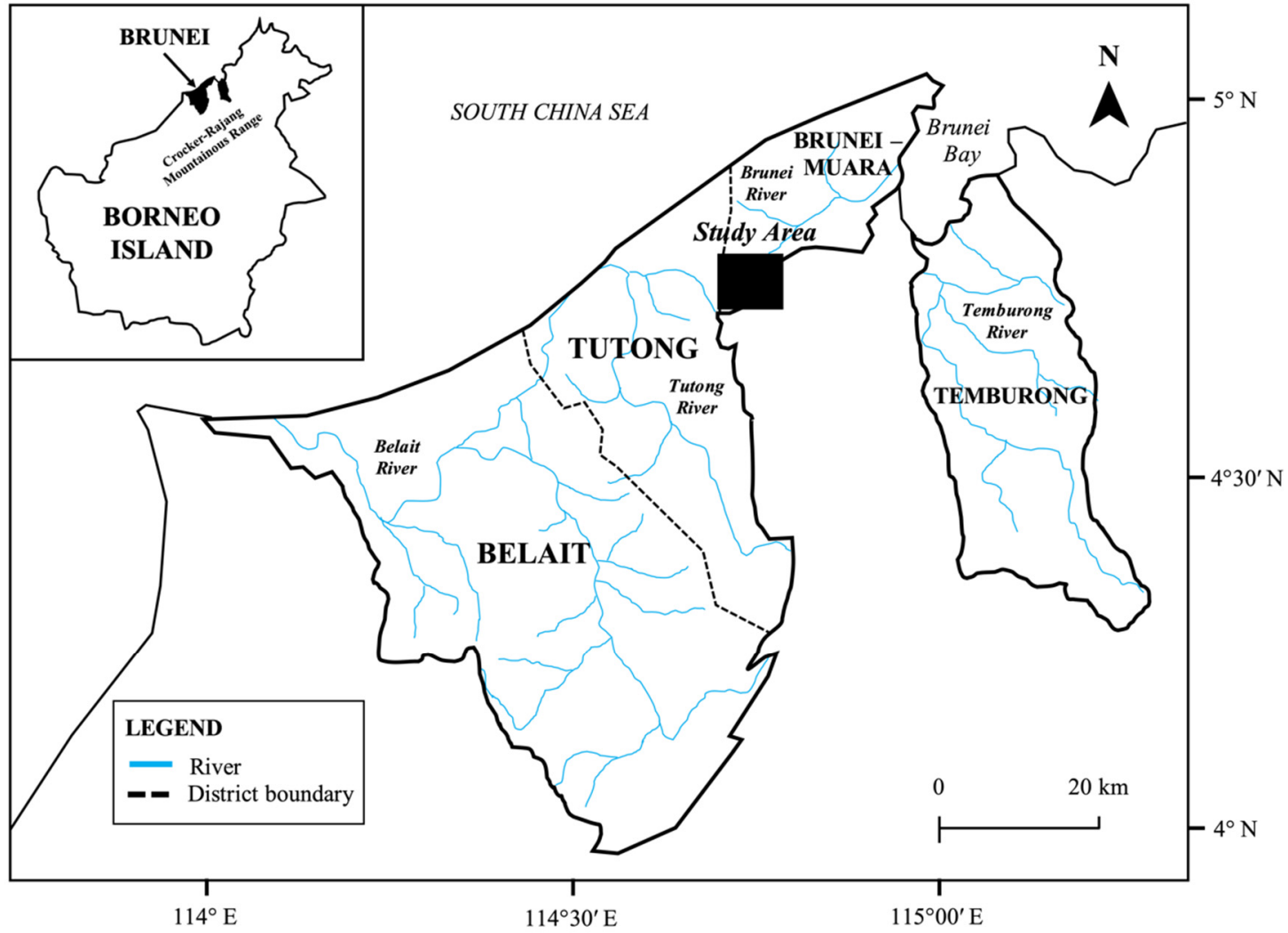

Figure 1. Map of Brunei Darussalam showing the four major river basins and location of the study area; Inset map of Borneo Island showing the location of Brunei Darussalam.

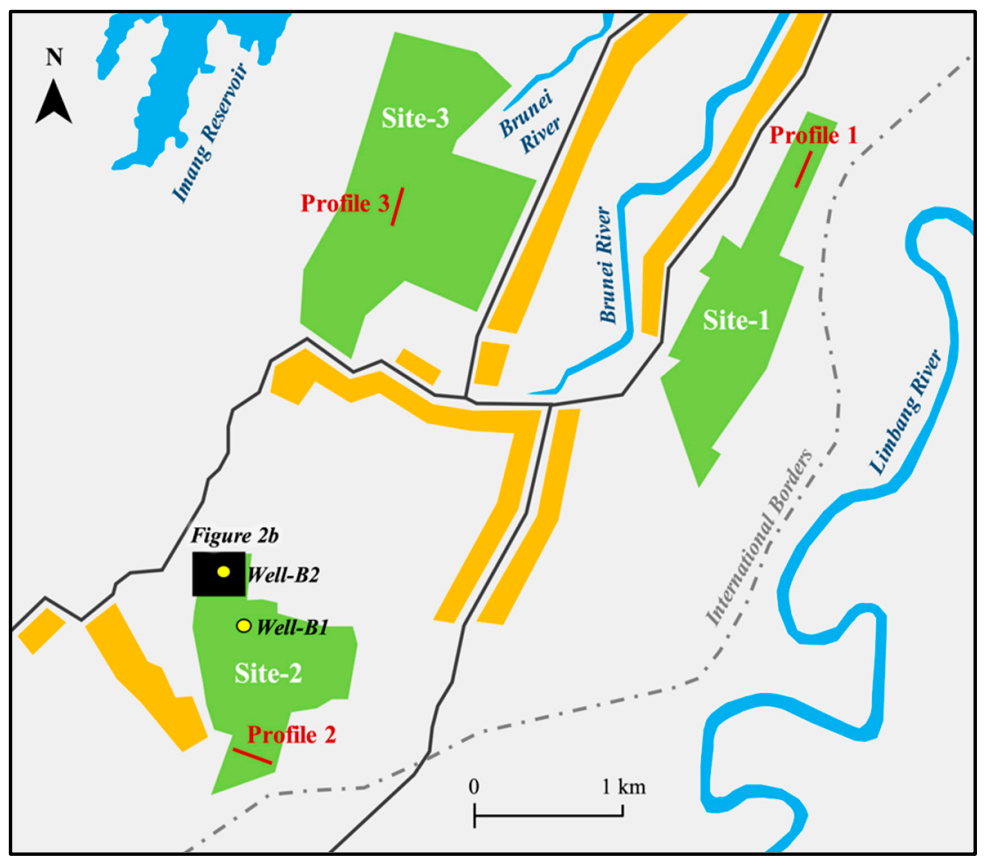

(a)

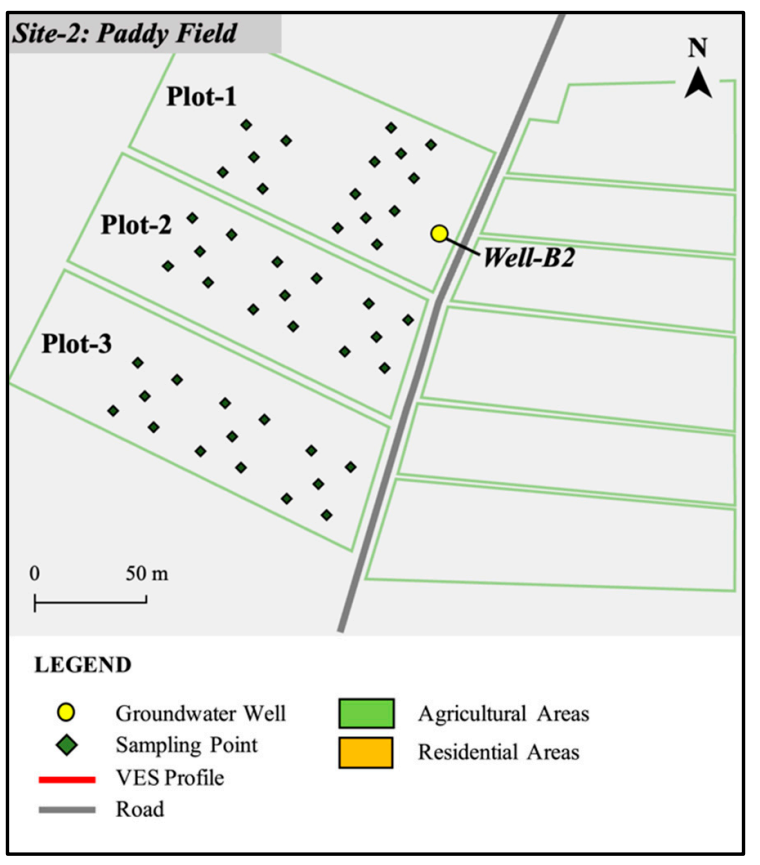

(b)

Figure 2. (a) Map of the study area showing locations of Sites 1-3, VES profiles and groundwater wells; and (b) Map of site-2 showing locations of soil sampling Plots 1-3.

Brunei Darussalam has a tropical climate characterised by high temperatures and humidity throughout the year. The average annual temperature is about $28^{\circ} \mathrm{C}$, and rainfall 
exceeds $2900 \mathrm{~mm}$ throughout the country, with regular high-intensity precipitation [23]. Rainfall events show a seasonal pattern with two wet and dry seasons. The wet seasons are from October to January and May to July, and the dry seasons are from February to March and June to August [23].

\subsubsection{Geological and Hydrogeological Setting}

The Brunei basin is situated on the north-western edge of Borneo Island adjacent to the Crocker-Rajang mountainous range. It was formed in the Early Miocene due to the subsequent uplift and erosion of this mountainous range, which resulted in deltaic sedimentation into basin depocenters [24]. Rocks of the Oligocene to Holocene age are up to 15 kilometres thick, and the sediment deposition occurs within the coastal plain to the shallow and deep marine environments [25].

The study area, in particular, is situated on recent sediments, possibly overlying two older stratigraphic units, namely the Setap Shale and Belait formations (Figure 3). The Setap Shale formation consists of thick deep-marine shales with occasional thin monotonous clay and turbidite sandstone intervals. On the other hand, the Belait formation consists of alternating sandstones and shales deposited in coastal plain to shallow marine environments [25]. A recent study of ground investigation for the Brunei Temburong Bridge revealed extremely heterogeneous geology with the top of the Belait Formation varying between 10 and over $60 \mathrm{~m}$ deep across the Brunei Bay [26]. Furthermore, rocks of Pleistocene to recent age consist primarily of clay, sand, and silt believed to be associated with alluvial floodplain to shallow marine deposition [25].

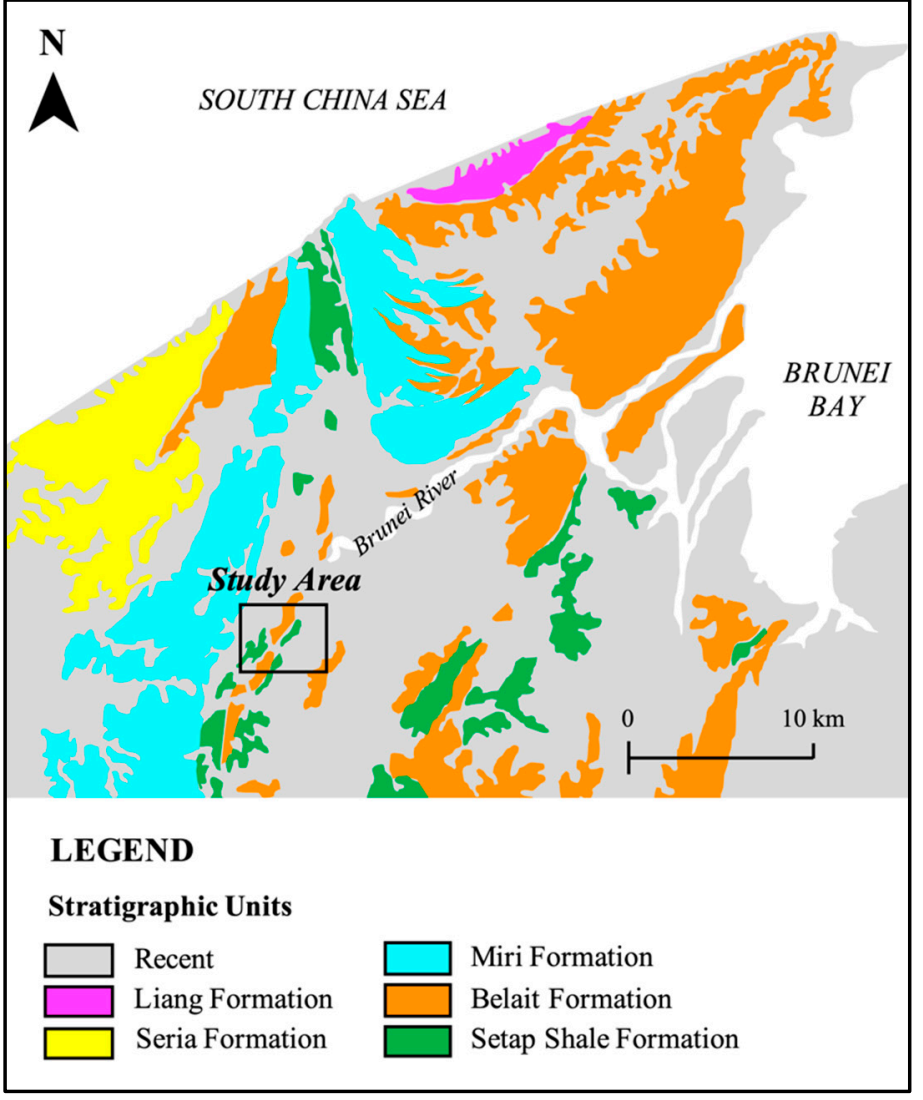

(a)

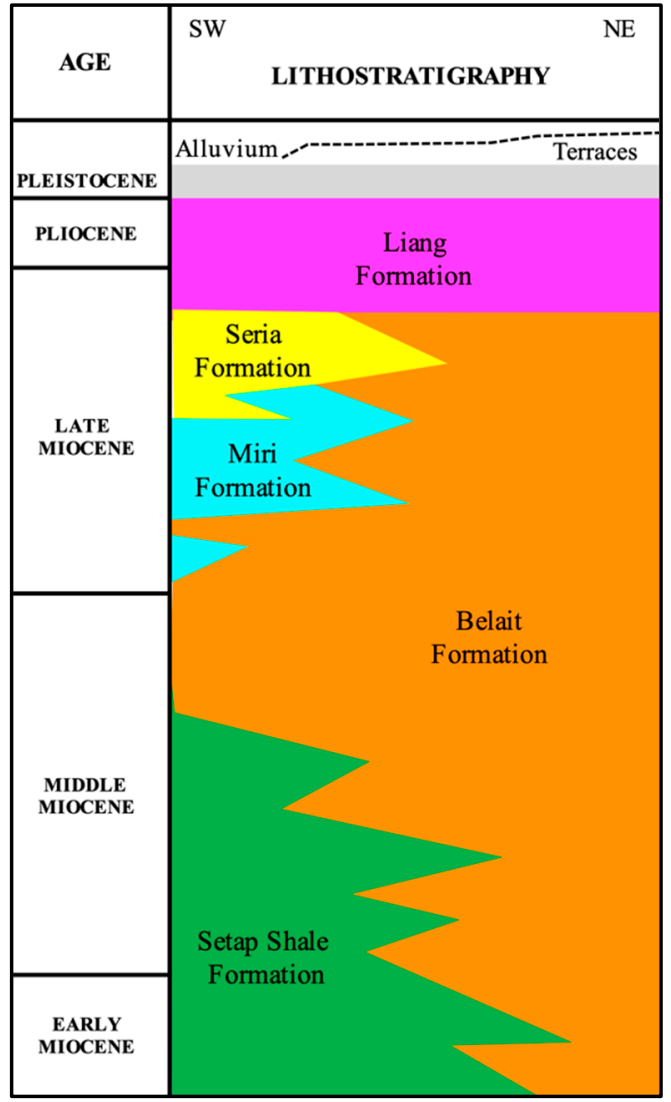

(b)

Figure 3. (a) Geological map of Brunei-Muara District and the study area; (b) Litho-chronostratigraphic cross-section of onshore central Brunei-Muara District (modified after [25]). 
Brunei Darussalam is drained by river basins, namely the Brunei, Tutong, Belait, and Temburong Rivers [27]. The study area belongs to the Brunei river basin, which drains towards the northeast and into Brunei Bay (Figure 3a). The upper parts of this river are a significant source of fresh water for the urban water supply. Surface water, in particular, accounts for more than $99.5 \%$ of the freshwater supply for domestic, industrial, and agricultural use in the country, with less than $1 \%$ coming from groundwater resources for potable water [28].

Limited groundwater reserves have been identified in the Liang and Labi areas of the Belait District $[22,28]$. A recent study shows that the groundwater recharge in Brunei can reach values of over $800 \mathrm{~mm} / \mathrm{a}$, and the depth to groundwater level is generally shallow and mostly up to $20 \mathrm{~m}$ below ground level [29]. Furthermore, a study investigated the local groundwater table within a shallow coastal aquifer in the Berakas area of Brunei-Muara District using the seismic refraction method [30]. In addition, this study also looked into the water quality of the nearby springs [30]. Only limited water quality studies in the region have been conducted [31].

\subsubsection{Land Use and Irrigation System}

Rice is one of the major irrigated crops in Brunei, with about 852 ha of agricultural land. The Brunei-Muara District contributes about $80 \%$ of the nation's rice production [28]. However, the country can only meet $8.23 \%$ of the total demand of 30,517 metric tons in 2020 [32]. Significant soil constraints for rice cultivation are extreme acidity, low cation exchange capacity, and low phosphorus content $[13,33]$. The study area also suffers from a lack of water availability to grow rice throughout the year [34].

Over the past four decades, the country's irrigation system has entirely depended on surface water resources [28]. In the study area, the irrigation water mainly originated from the Imang reservoir (Figure 2a). It is reported that the Imang Dam can retain about 8 million cubic meters of rainfall [34], although this water supply is still insufficient to supply water for irrigation in the region, especially during the dry season. As a result, farmers have to schedule their planting to coincide with the rainy season.

\subsection{Field Survey and Data Analysis}

Field surveys were conducted in the study area using the geoelectrical resistivity method. The method estimates the variation in the ground's resistivity by injecting an artificially generated current through a set of electrodes $(\mathrm{AB})$ into the underground medium and measuring the voltage differences at the potential electrodes $(\mathrm{MN})[35,36]$. The resistivity can be determined from Ohm's law using the voltage differences for a known current and correcting the current geometrical pathway through the earth. Therefore, from the known current (I) and voltage (V), the apparent resistivity ( $\rho$ ) can be written as:

$$
\rho \mathrm{a}=\frac{\mathrm{k} \Delta \mathrm{V}}{\mathrm{I}}
$$

where ' $k$ ' is the geometric factor. The general expression for the geometric factor can be written as:

$$
\mathrm{k}=\frac{2 \pi}{\frac{1}{\mathrm{AM}}-\frac{1}{\mathrm{BM}}-\frac{1}{\mathrm{AN}}+\frac{1}{\mathrm{BN}}}
$$

The present study used the vertical electrical sounding (VES) technique in 2021 using the ARES II resistivity meter (GF Instruments, Brno, Czech Republic). The VES survey locations were flat, and the topographical elevations above mean sea level was about $3 \mathrm{~m}$, $10 \mathrm{~m}$, and $4 \mathrm{~m}$ at sites 1,2 , and 3, respectively. Fifteen VES stations with a total of three hundred and seventy-five (375) sounding data points covering the study area along three profiles were measured. In addition, spacing between the current electrodes $(A B)$ for the adopted Schlumberger array varied between 2 and $602 \mathrm{~m}$, while the spacing between the potential electrodes (MN) varied between 0.4 and $40 \mathrm{~m}$ to achieve the desired current penetration and depth of investigation of $200 \mathrm{~m}$ from the ground surface. The Schlumberger 
array offers a reasonable compromise between the depth of investigation and the vertical resolution [37]. The current electrode $(\mathrm{AB})$ remained outside the potential electrodes $(\mathrm{MN})$ for this configuration. As a result, the distance between $A B$ is much larger than the distance between $\mathrm{MN}$ (distance $\mathrm{AB} \times 0.2>$ distance $\mathrm{MN}$ ). In this case, the apparent resistivity was calculated using Equation (3):

$$
\rho \mathrm{a}=\frac{\pi\left(\mathrm{s}^{2}-\mathrm{a}^{2}\right)}{4 \mathrm{a}} \frac{\Delta \mathrm{V}}{\mathrm{I}}
$$

where ' $s$ ' is the distance between $A B$ and ' $a$ ' is the distance between MN.

IPI2WIN software (version 3.5b, 3.06.16) was used to perform the one-dimensional (1D) inversion of the sounding curves obtained from the field data (at each VES station). Inversion is performed separately for each sounding curve using a variant of the Newton algorithm for the least number of layers [38]. The Root Mean Square (RMS) errors between the calculated and modelled resistivity values are listed in Table 1. For detailed interpretation using the IPI2WIN software, see the Supplementary Data (Figures S1-S6). The results are represented as geoelectrical sections (Figures 4-6) from which different geoelectrical resistivities layers, layer thicknesses, and their spatial distribution were defined. The geoelectrical boundaries of each layer were drawn from the interpreted field data in conjunction with the geology and the lithological log of nearby shallow boreholes.

Table 1. Summary of RMS errors at each VES station 1-5 of Profiles 1-3.

\begin{tabular}{cccccc}
\hline \multirow{2}{*}{ Profile } & \multicolumn{5}{c}{ RMS Error (\%) } \\
\cline { 2 - 6 } & Station 1 & Station 2 & Station 3 & Station 4 & Station 5 \\
\hline 1 & 20.3 & 15.5 & 16.1 & 11.8 & 13.5 \\
2 & 11.9 & 6.6 & 17.5 & 16.1 & 16.5 \\
3 & 26 & 13.4 & 6.5 & 7.3 & 14.1 \\
\hline
\end{tabular}

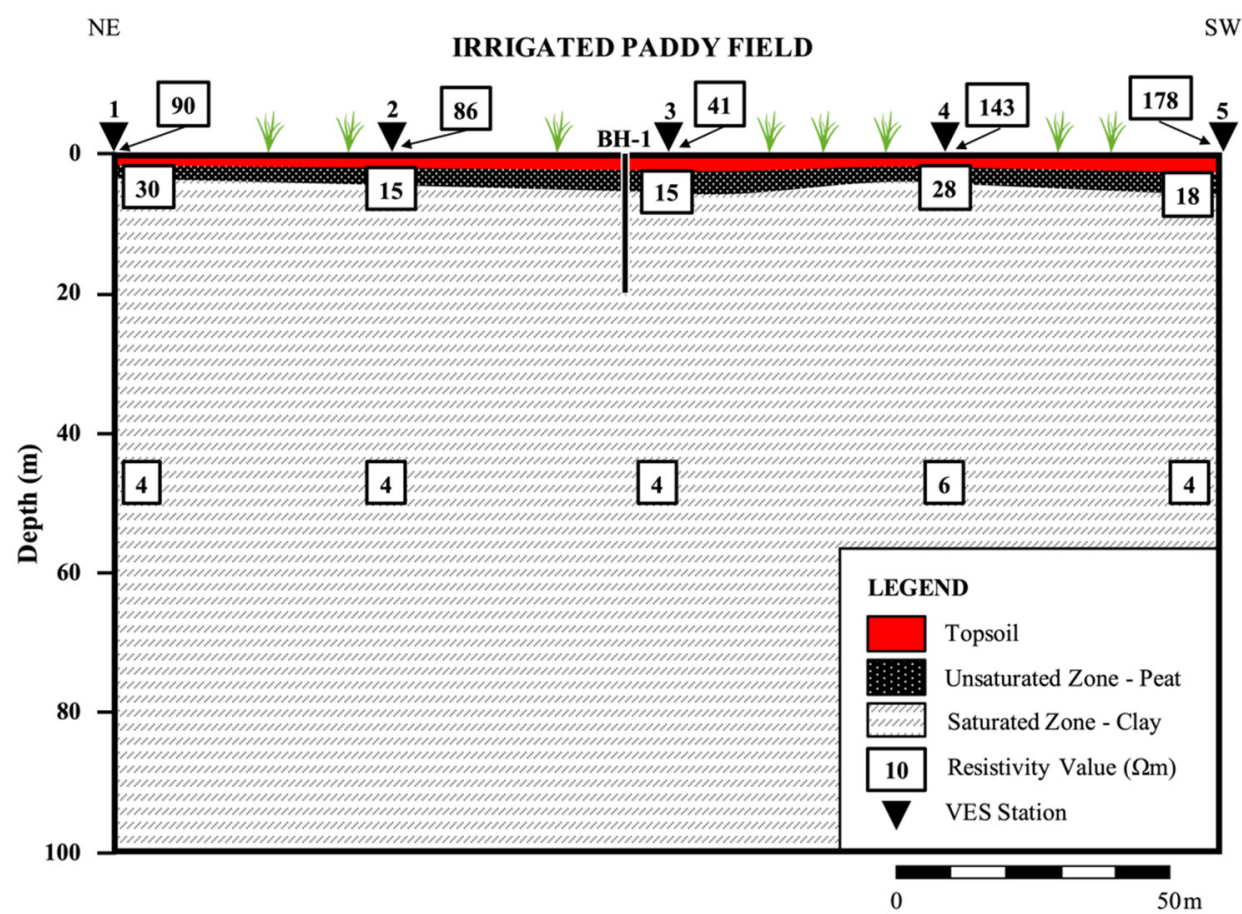

Figure 4. Geoelectrical section of Profile 1 at Site-1. 
NON-IRRIGATED FIELD

W

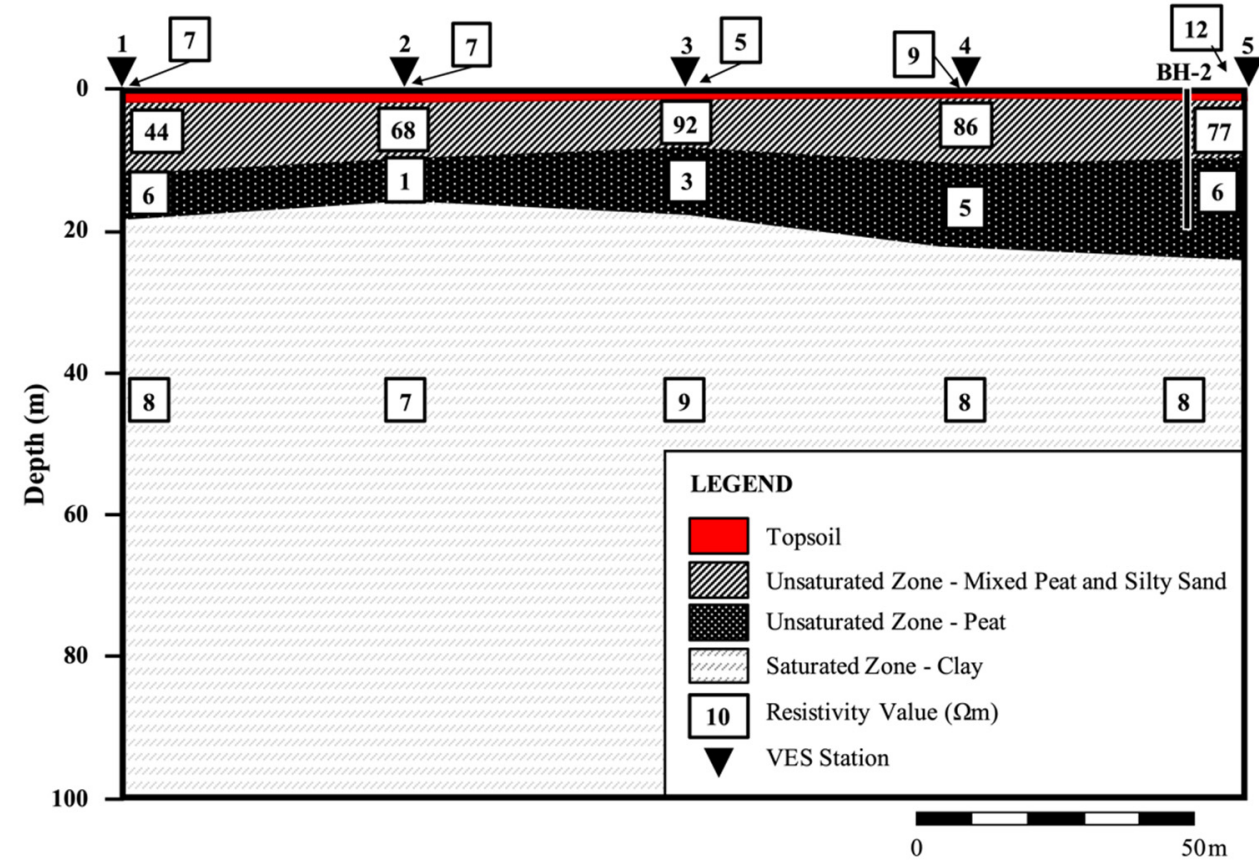

Figure 5. Geoelectrical section of Profile 2 at Site-2.

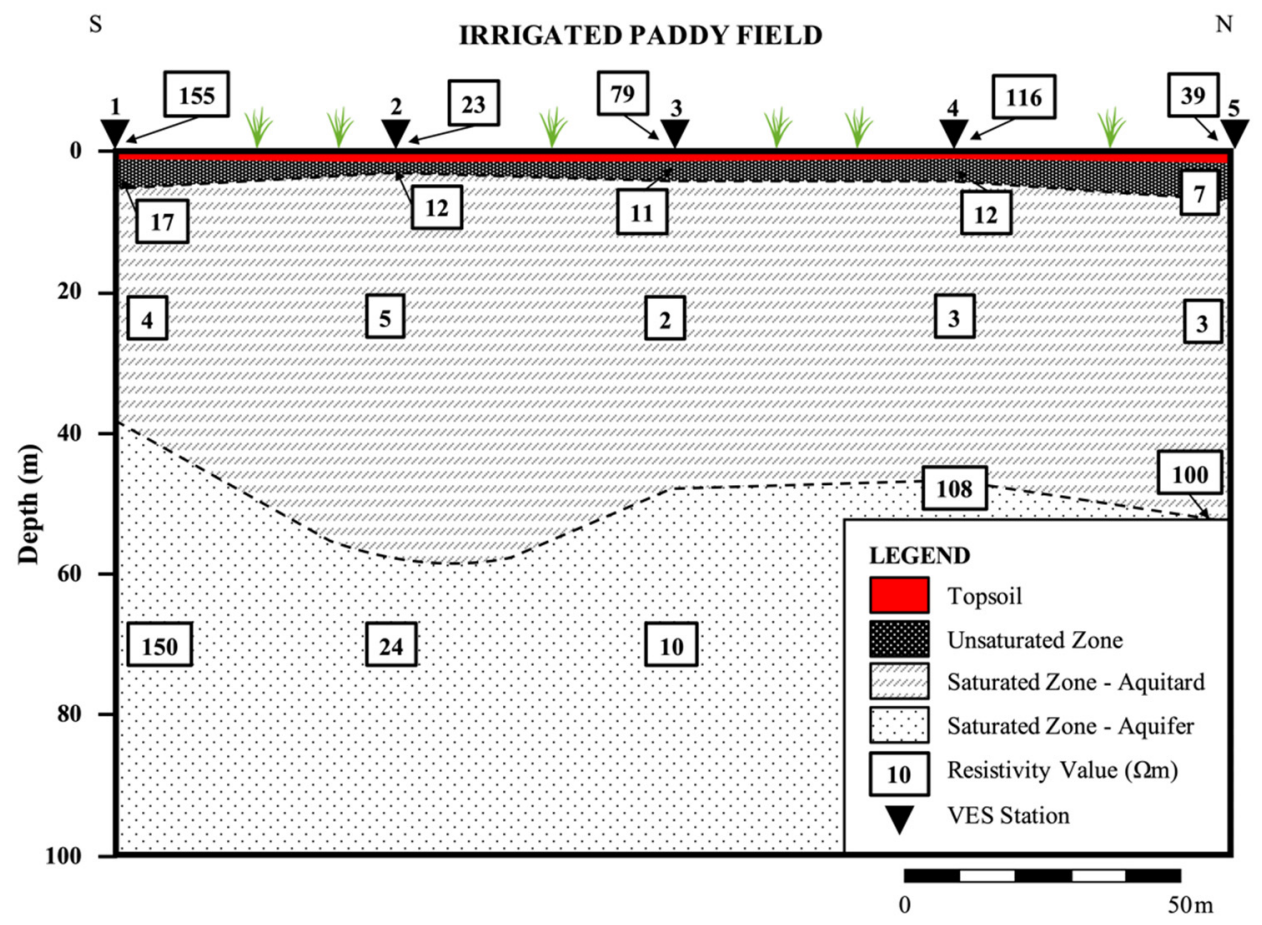

Figure 6. Geoelectrical section of Profile 3 at Site-3.

\subsection{Groundwater Sampling and Analysis}

Groundwater samples were collected from groundwater Well-B1 and Well-B2 at site-2 in August 2020 (Figure 2). The water wells were constructed in June 2020 by the Brunei Department of Agriculture and Agrifood for irrigation purposes [39]. Borehole drilling was carried out using a straight rotary drilling method to depths of $96 \mathrm{~m}$ and $86 \mathrm{~m}$ below ground level at Well-B1 and Well-B2, respectively. Screened intervals were placed in saturated clayey sand layers at depths $84 \mathrm{~m}$ to $95 \mathrm{~m}$ in Well-B1 and $76 \mathrm{~m}$ to $82 \mathrm{~m}$ in Well-B2. 
Preliminary groundwater pumping tests of both wells revealed low groundwater yields and recovery. The obtained transmissivity and hydraulic conductivity values of the aquifer units were $0.53 \mathrm{~m}^{2} /$ day and $0.059 \mathrm{~m} /$ day at Well-B1 and $0.33 \mathrm{~m}^{2} /$ day and $0.055 \mathrm{~m} /$ day at Well-B2, respectively. The low hydraulic conductivity values are associated with the clay sediments within the aquifer units.

Two groundwater samples were gathered, one from each well. The groundwater samples were collected in watertight polyethene bottles $(1 \mathrm{~L})$ and conserved using standard protocols (metals by filtering and acidulating with concentrated nitric acid). The $\mathrm{pH}$ and Electrical Conductivity (EC) parameters were conducted onsite on the day of sampling. The Total Dissolved Solids (TDS) parameters were estimated from the EC measurements based on the linear TDS-EC relationship [40].

Physical and chemical analysis of the groundwater samples was conducted at the CHEMSAIN laboratory in Kuching, East Malaysia. The analysis was carried out as per the procedure laid down by the American Public Health Association [41]. In addition, trace element analysis was conducted at the Swiss Federal Institute of Aquatic Science and Technology (Eawag) laboratory in Switzerland. Values for trace metals were obtained through graphite furnace atomic absorption spectrometry (GFASS, AAS contrAA ${ }^{\circledR} 700$ Analytik Jena, Reinach, Switzerland). Furthermore, quantitative analysis was conducted to check the charge balance error for the groundwater samples using the software PhreeqCI [42]. Additionally, bicarbonate ions of the samples were iteratively calculated using the above software.

Physical and chemical parameters of the analysed groundwater samples were compared with the standard limits for irrigation use adopted from the Food and Agriculture Organization of the United Nations (FAO, Rome, Italy) [43]. In addition, the water quality indices for irrigation suitability were evaluated [43-45]. The sodium absorption ratio (SAR), soluble sodium percentage (SSP), and magnesium absorption ratio (MAR) were calculated by using the following equations:

$$
\begin{gathered}
\mathrm{SAR}=\frac{\mathrm{Na}^{+}}{\sqrt{\left(\mathrm{Ca}^{2+}+\mathrm{Mg}^{2+} / 2\right)}} \\
\operatorname{SSP}(\%)=\frac{\left(\mathrm{Na}^{+}+\mathrm{K}^{+}\right)}{\left(\mathrm{Ca}^{2+}+\mathrm{Mg}^{2+}+\mathrm{Na}^{+}+\mathrm{K}^{+}\right)} \times 100 \\
\operatorname{MAR}(\%)=\frac{\mathrm{Mg}^{2+}}{\left(\mathrm{Ca}^{2+}+\mathrm{Mg}^{2+}\right)} \times 100
\end{gathered}
$$

where the quantities of $\mathrm{Na}^{+}, \mathrm{Ca}^{2+}, \mathrm{Mg}^{2+}$, and $\mathrm{K}^{+}$are expressed in meq/l.

\subsection{Soil Sampling and Analysis}

Forty-five clayey soil samples were collected from site-2 and analysed for physical and chemical properties. Samples were divided into three groups of fifteen based on their allocated plots (Figure 2b), with plot-1 located closest to the groundwater Well-B2. A soil auger (Eijkelkamp, Giesbeek, The Netherlands) with a fixed diameter of $7 \mathrm{~cm}$ was used to core the samples to $15 \mathrm{~cm}$ depth manually. Physicochemical analysis of the soil samples was conducted in-house at the Environmental and Life Sciences laboratory at Universiti Brunei Darussalam.

Soil pH was measured using a pH meter (Orian Star A211, Thermo Scientific, Waltham, MA, USA) on the day of soil sampling by diluting $10 \mathrm{~g}$ of the fresh soil sample in a cup with distilled water with soil to water ratio of 1:2 [46]. The soil moisture (\%) was determined by oven-drying $10 \mathrm{~g}$ of the fresh soil sample at $105^{\circ} \mathrm{C}$ for $24-\mathrm{h}$. The weight of the sample before and after oven drying was recorded, and the soil moisture was calculated by using Equation (7) [46]: 


$$
\text { Moisture }(\%)=\frac{[\text { Initial wet weight }(\mathrm{g})-\text { final oven dried weight }(\mathrm{g})]}{\text { Initial wet weight }(\mathrm{g})} \times 100(\%)
$$

The remaining fresh soil samples were air-dried at room temperature for one month. Air-dried soils were then ground with a pestle and mortar, sieved using a $2 \mathrm{~mm}$ sieve, and ground with a ball mill. For determination of organic matter $(\mathrm{OM})$ content, $10 \mathrm{~g}$ of the sieved finely-ground soil samples were placed into individual $50 \mathrm{~mL}$ crucibles and oven-dried at $105^{\circ} \mathrm{C}$ for $24 \mathrm{~h}$. After oven-drying, the individual samples were reweighed and put into a Gallenkamp Muffle Furnace Size 2 (Cambridge, United Kingdom) for $2 \mathrm{~h}$ at $550^{\circ} \mathrm{C}$. After $2 \mathrm{~h}$, the samples were transferred to a desiccator to cool entirely before reweighing. Once cooled, the sample weight was recorded, and the ash (\%) was calculated using Equation (8). Finally, the OM content (\%) of the soil was calculated using Equation (9) [46]:

$$
\begin{gathered}
\text { Ash }(\%)=\frac{\text { Ash mass of soil after furnace }(\mathrm{g})}{\text { Oven }- \text { dried mass of soil }(\mathrm{g})} \times 100(\%) \\
\text { OM }(\%)=100(\%)-\text { Ash }(\%)
\end{gathered}
$$

Soil total nitrogen and phosphorous concentrations were determined by the Kjeldahl method [46] by digesting approximately $1.0 \mathrm{~g}$ of air-dried, finely ground, and sieved soil samples in concentrated sulphuric acid $\left(\mathrm{H}_{2} \mathrm{SO}_{4}\right)$ with one Kjeltab CU 1.5 catalyst tablet, using a block digester (BD-46, LACHAT Instruments, Loveland, CO, USA). Total nitrogen and phosphorous concentrations were determined using a Flow Injector Analyser (FIAstar 5000, Höganäs, Sweden), following the procedures in FIAstar 5000's user manual. For the determination of total potassium, magnesium, and calcium concentration, approximately $0.2 \mathrm{~g}$ of air-dried, finely ground, and sieved soil samples were acid-digested using a block digestor (BD-46, LACHAT Instruments, Loveland, CO, USA) with 70\% sulphuric acid and hydrogen peroxide [44], and the concentrations of total magnesium, calcium, and potassium were measured using Flame Atomic Absorption Spectrophotometer (AAS; Shimadzu AA-6701, Kyoto, Japan).

One-way analysis of variance (One-way ANOVA) analysis was conducted for each parameter in Rstudio ( $\mathrm{R}$ x64 version 4.1.1) statistical software $[47,48]$ to determine the significant differences in soil physical and chemical properties between the three designated plots (plot-1, plot-2, and plot-3) within site-2. Soil moisture, OM, and ash content were arcsine-transformed, while total nitrogen concentrations were $\log _{10}$-transformed prior to ANOVA. Assumptions of normality and equal variances were tested and were not violated for all other soil parameters. Tukey's Honest Significant Difference (TukeyHSD) test was used to determine differences in soil properties between the three sampling plots. The superscripts use the letters $(a, b$, and $c)$ to explain significant differences between the plots. The soil properties were considered significantly different if $p<0.05$.

\section{Results}

\subsection{Geoelectrical Sections}

Profile 1 lies at the north-eastern part of the study area at site-1 (Figure 2a). Five VES stations were measured along this profile with a total length of $200 \mathrm{~m}$ (Figure 4). The geoelectrical section (Figure 4) shows that this section consists of three geoelectrical layers. The first uppermost layer is characterised by high resistivity values ranging from 41 to $180 \Omega \mathrm{m}$, with layer thickness varying between 0.6 and $1 \mathrm{~m}$. The underlying second layer is characterised by moderate resistivity ranging from 15 to $30 \Omega \mathrm{m}$ extending to about 3 to $6 \mathrm{~m}$ below ground level. The third geoelectrical layer of this section has low resistivities ranging from 4 to $6 \Omega \mathrm{m}$. This layer extends to about $100 \mathrm{~m}$ depth below ground level and possibly to greater depths. Soil lithology information from an existing shallow borehole (Figure 4; BH-1) showed that the soil lithology consists of peat soil from ground level to $3 \mathrm{~m}$ depth below ground level, followed by brownish to greyish clay from 3 to $20 \mathrm{~m}$ depth below ground level. 
Profile 2 is located southwest of Profile 1 at site-2 (Figure 2a), where five vertical electrical sounding stations were measured, extending for about $200 \mathrm{~m}$ (Figure 5). The geoelectrical section (Figure 5) shows four geoelectrical layers. The first uppermost layer is deduced by low resistivities ranging from 5 to $12 \Omega \mathrm{m}$ with a layer thickness ranging from 0.5 to $0.9 \mathrm{~m}$. A second layer was observed underneath the first layer characterised by comparatively high resistivity values ranging from 44 to $92 \Omega \mathrm{m}$ were observed. This layer extends to about 9 to $14 \mathrm{~m}$ below ground level. The third geoelectrical layer has low electrical resistivities ranging from 1 to $6 \Omega \mathrm{m}$. This layer extends to about 13 to $28 \mathrm{~m}$ below ground level. The fourth layer in this section was recognised with electrical resistivity values ranging from 7 to $9 \Omega \mathrm{m}$. This layer extends to about $100 \mathrm{~m}$ depth below ground level and possibly to greater depths. An existing shallow borehole (Figure 5; BH-2) showed that the soil lithology consists of dark peat soil with decomposed organic materials (roots) from ground level to $7 \mathrm{~m}$ depth below ground level and again at $12 \mathrm{~m}$ to $20 \mathrm{~m}$ below ground level. Silty sand was observed between $7 \mathrm{~m}$ and $12 \mathrm{~m}$ below ground level.

Profile 3 is located north of the study area at site-3 (Figure $2 a$ ). It is covered by 5 VES stations. It extends for a total length of $200 \mathrm{~m}$ (Figure 6). Four geoelectrical layers were deduced. The first uppermost layer is characterised by high resistivity values ranging from 23 to $155 \Omega \mathrm{m}$. The thickness of this layer is about 0.5 to $0.7 \mathrm{~m}$. This layer is followed by a second layer characterised by resistivities ranging from 7 to $17 \Omega \mathrm{m}$. The second layer extends to about 3 to $14 \mathrm{~m}$ below ground level. A third geoelectrical layer is characterised by low resistivity values ranging from 2 to $5 \Omega \mathrm{m}$. This third layer extends to about 40 to $60 \mathrm{~m}$ below ground level. This layer is followed by the fourth layer characterised by moderate to high resistivities ranging from 10 to $150 \Omega \mathrm{m}$, extending to about $100 \mathrm{~m}$ depth below ground level and possibly to greater depths.

\subsection{Physicochemical Properties of Groundwater}

The physicochemical properties of the analysed groundwater samples from Wells B1 and B2 at site-2 are given in Table 2. The charge balance errors of the analysed groundwater samples in this study were less than $5 \%$. The concentration values of the six metals and trace metals $(\mathrm{Fe}, \mathrm{Pb}, \mathrm{Cu}, \mathrm{Zn}, \mathrm{Cd}$, and $\mathrm{Cr}$ ) indicate that the abundance of metals and trace metals of the groundwater samples are in the following order: $\mathrm{Fe}>\mathrm{Zn}>\mathrm{Cu}>\mathrm{Cr}>\mathrm{Pb}>\mathrm{Cd}$ for Well-B1 and $\mathrm{Fe}>\mathrm{Zn}>\mathrm{Pb}>\mathrm{Cr}>\mathrm{Cu}>\mathrm{Cd}$ for Well-B2. The calculated irrigation water quality indices of the analysed groundwater samples are given in Table 3.

Table 2. Physiochemical parameters of the groundwater samples from Well-B1 and Well-B2 with the FAO acceptable limits for irrigation water [43].

\begin{tabular}{|c|c|c|c|}
\hline Parameters & Well-B1 & Well-B2 & FAO \\
\hline $\mathrm{pH}$ & 8.1 & 8.6 & $6.5-8.4$ \\
\hline Electrical Conductivity (dS/m) & 2.86 & 2.3 & $0.25-3$ \\
\hline Total Dissolved Solids (mg/L) & 1830 & 1472 & $<2000$ \\
\hline Hardness as Calcium carbonate $(\mathrm{mg} / \mathrm{L})$ & 105 & 673 & $<150$ \\
\hline Sodium $(\mathrm{mg} / \mathrm{L})$ & 487 & 370 & $<920$ \\
\hline Magnesium (mg/L) & 13.3 & 143 & $<60$ \\
\hline Calcium (mg/L) & 20 & 34.2 & $<400$ \\
\hline Potassium $(\mathrm{mg} / \mathrm{L})$ & 7.34 & 28.5 & $<30$ \\
\hline Nitrate-Nitrogen (mg/L) & 0.04 & 0.18 & $<10$ \\
\hline Ammoniacal-Nitrogen (mg/L) & 3.94 & 8.23 & $<5$ \\
\hline Carbonate $(\mathrm{mg} / \mathrm{L})$ & Absent & Absent & $<3$ \\
\hline Bicarbonate (mg/L) & 671 & 397 & $<150$ \\
\hline Phosphorous (mg/L) & 0.06 & 0.09 & $<5$ \\
\hline Sulphate (mg/L) & 59 & 243 & $<960$ \\
\hline Chloride (mg/L) & 431 & 426 & $<1050$ \\
\hline
\end{tabular}


Table 2. Cont.

\begin{tabular}{cccc}
\hline Parameters & Well-B1 & Well-B2 & FAO \\
\hline Fluoride (mg/L) & 0.35 & 0.48 & $<1$ \\
Iron (mg/L) & 1.88 & 716 & $<5$ \\
Lead (mg/L) & 0.0004 & 0.015 & $<5$ \\
Copper (mg/L) & 0.00127 & 0.004 & $<0.2$ \\
Zinc (mg/L) & 0.056 & 0.023 & $<2$ \\
Cadmium (mg/L) & 0.00005 & 0.00009 & $<0.01$ \\
Chromium (mg/L) & 0.0005 & 0.012 & $<0.1$ \\
\hline
\end{tabular}

Table 3. Water quality indices of the groundwater samples from Well-B1 and Well-B2 with the acceptable limits for irrigation suitability.

\begin{tabular}{ccccc}
\hline Parameters & Well-B1 & Well-B2 & Limits & Source \\
\hline Sodium Absorption Ratio & 21 & 6.2 & $1-26$ & \\
Soluble Sodium Percentage (\%) & 91.1 & 55.5 & $<60$ & [43-45] \\
Magnesium Absorption Ration (\%) & 52.3 & 87.3 & $<50$ & \\
\hline
\end{tabular}

\subsection{Physicochemical Properties of Soil}

The physicochemical properties of the analysed soil samples based on their designated plots (plot-1, plot-2, and plot-3) are presented in boxplots in Figure 7. It can be seen that the values of soil $\mathrm{pH}$, moisture, ash content, total nitrogen, and total phosphorous are lowest at plot-1 compared to the other plots. Average concentrations of total potassium across the sites vary between 6.5 and $7 \mathrm{mg} / \mathrm{g}$, whereas average concentrations of total magnesium range between 1.2 and $1.4 \mathrm{mg} / \mathrm{g}$. Total calcium did not show a significant difference in concentrations across the different plots.

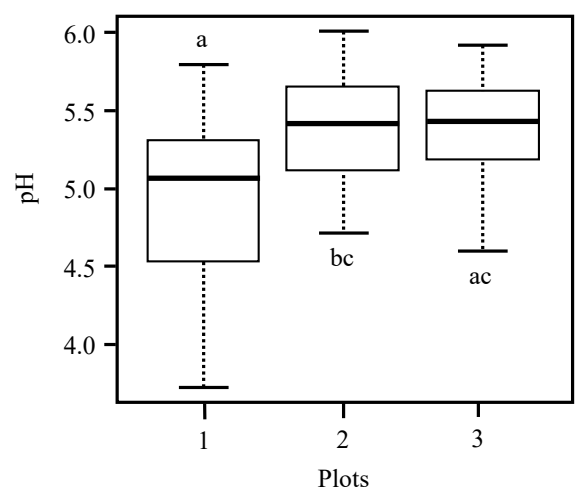

(a)

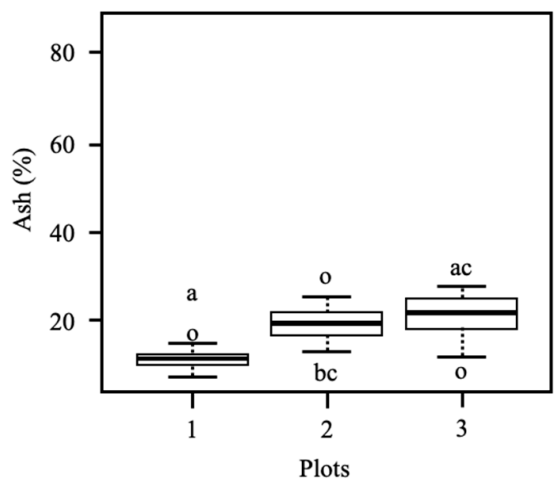

(c)

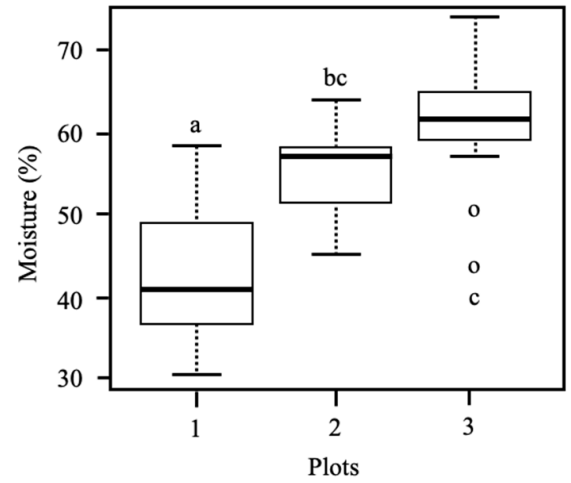

(b)

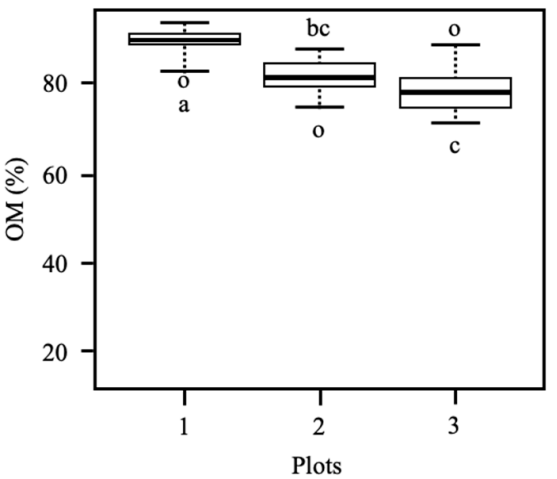

(d)

Figure 7. Cont. 


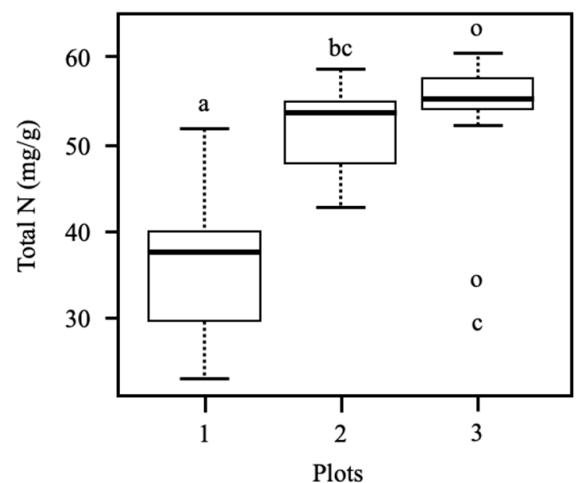

(e)

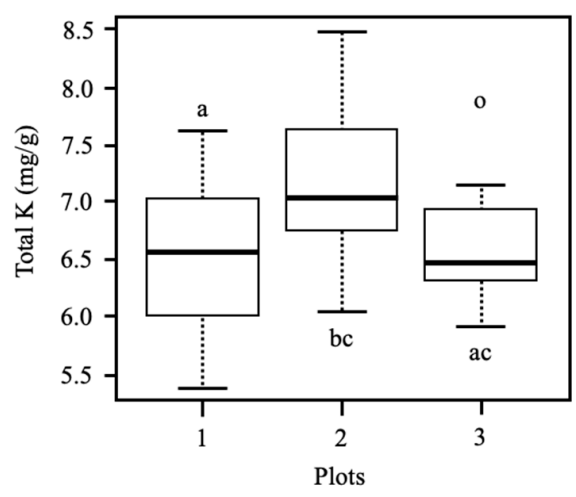

(g)

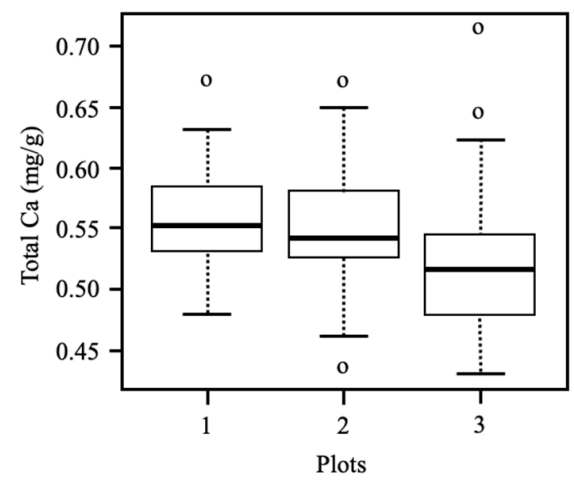

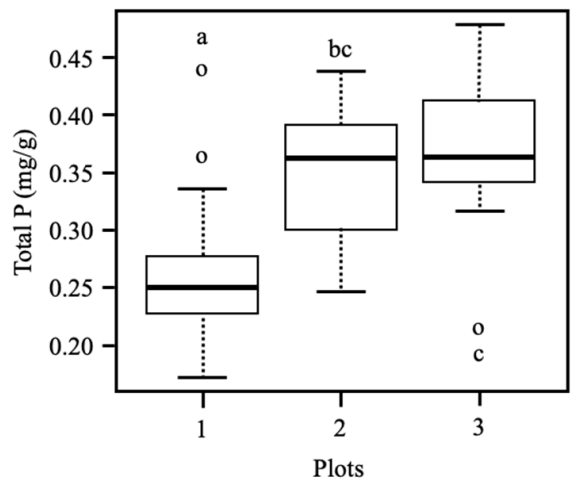

(f)

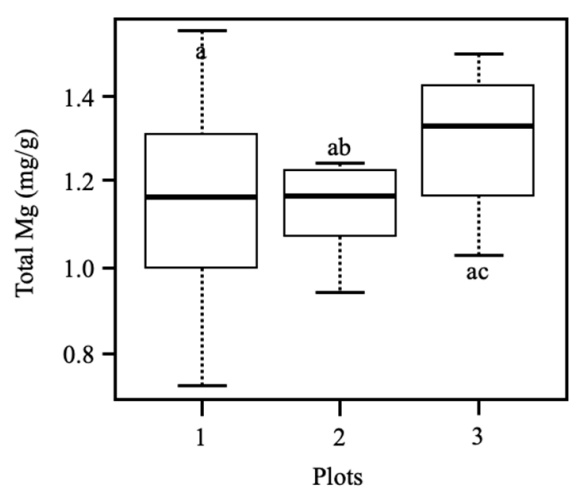

(h)

(i)

Figure 7. Differences in soil physicochemical properties at site-2: (a) $\mathrm{pH}$ values, (b) moisture, (c) ash content, (d) organic matter content, (e) total nitrogen, (f) total phosphorous, (g) total potassium, (h) total magnesium, and (i) total calcium. Superscripts with different letters (a, b, and c) within a panel indicate significant differences. Hollow circles represent outliers, and the thick black line in the box represents the median.

Soil $\mathrm{pH}$, ash contents, and total potassium concentrations were significantly different between plots 1 and $2(p<0.05)$ but did not significantly differ between plots 1 and 3 and between plots 2 and 3. Soil moisture, OM content, total nitrogen, and total phosphorous concentrations were significantly different between plots 1 and 2 and between plots 1 and $3(p<0.001)$ but did not significantly differ between plots 2 and 3 . In addition, the total magnesium concentrations were significantly different between plots 2 and $3(p<0.05)$ but did not differ between plots 1 and 2 and between plots 1 and 3. No significant differences in total calcium concentrations were detected between any plots. 


\section{Discussion}

\subsection{Groundwater Potential}

The geoelectrical parameters obtained were used to generate earth models presented as subsurface stratigraphy based on effective resistivity of the underlying geological units from which potential aquifer zones were delineated [15]. The present study deduced three to four geoelectrical layers based on the sounding data (Figures 4-6). These layers include topsoil, unsaturated, and saturated zones.

The uppermost layer in all the sections was inferred as topsoil. This layer is considered thin with comparatively high resistivity values at sites 1 and 3. Topsoil often has higher resistivity values as they are located above the water table and are significantly drier [16]. Resistivity correlation with soil lithology from nearby boreholes confirmed the presence of peat in the topsoil layer.

The geoelectrical sections in this study were also dominated by low resistivities (less than $10 \Omega \mathrm{m}$ ), mainly observed in the third layer of all the sections. Studies have shown that low resistivity values within the underlying layers were likely to be attributed to high ion concentrations and fine-grained sediments such as silt and clay [20,21]. Other studies found that fresh groundwater in sedimentary settings yields low resistivities ranging between 10 and $100 \Omega \mathrm{m}[16,20,21]$.

The fourth layer at site- 3 was considered a potential aquifer zone based on favourable resistivity contrasts and resistivity values of this layer which range between 10 and $150 \Omega \mathrm{m}$. This layer is observed at depths of about 30 to $60 \mathrm{~m}$ from the surface. In addition, the profile line is aligned with the flow direction of the nearby Brunei river (Figure 2a). Thus, this layer could represent a former riverbed. Furthermore, the third layer at this site was considered as aquitard based on the low resistivity readings ( 2 to $5 \Omega \mathrm{m}$ ), which could potentially represent an impermeable clay zone. The saturated clay at site-1 showed similar resistivity readings ranging from 4 to $6 \Omega \mathrm{m}$. Our findings suggest that aquifer zones for groundwater irrigation use could potentially lie within the deeper geological units. However, this should be further confirmed by borehole drilling and hydraulic testing to determine the aquifer characteristics $[15,22]$.

Additionally, resistivity results show that the saturated zones were shallower at sites 1 and 3 and deeper at site-2. This could be explained by the effects of anthropogenic activities at the sites. Sites 1 and 3 are currently actively irrigated sites utilised for rice farming. The shallow groundwater levels at sites 1 and 3 are likely due to surface irrigation practices [10]. On the other hand, site-2 (survey area) is currently non-irrigated [39], suggesting that surface irrigation has not influenced the groundwater level, thus explaining the deeper groundwater level. Our findings suggest that surface irrigation water may be regarded as a significant source of recharge to the nearby groundwater, especially during the irrigation season $[5,12]$.

\subsection{Groundwater Suitability for Irrigation Use}

Groundwater from existing Wells B1 and B2 at site-2 were sampled and analysed for their physicochemical properties to assess its suitability for irrigation use [43-45]. Groundwater data (Table 2) showed that the water samples from both wells have an alkaline character with $\mathrm{pH}$ values of 8.1 and 8.6. The EC and TDS values of the groundwater samples from both the wells are considered doubtful for irrigation purposes, with a slight to moderate degree of restrictions on use due to potential salinity problems [43]. In addition, the total hardness (as calcium carbonate) of the groundwater sample from Well-B2 exceeds the FAO standard limits for irrigation purposes (>150 mg/L). The major cation and anion concentrations of the groundwater sample from Well-B1 are within the FAO acceptable limits for irrigation use except for bicarbonate [43]. Furthermore, the major cation and anion concentrations of the groundwater sample from Well-B2 are within the FAO acceptable limits for irrigation use except for magnesium, bicarbonate, and ammoniacal nitrogen. Concentrations of trace metals in both the groundwater samples are lower than the FAO limits for irrigation use except for iron (at Well-B2). 
As the wells were intended for irrigation purposes, the irrigation water quality indices were calculated (Table 3) and compared with the FAO standard limits for irrigation suitability [43-45]. The calculated irrigation water quality indices showed that the SAR value of the groundwater sample from Well-B1 is within limits for irrigation use. In contrast, the SSP and MAR values are higher than the FAO acceptable limits. On the other hand, the calculated SAR and SSP values of the groundwater sample from Well-B2 are within the acceptable limits for irrigation use. This also suggests that salinity effects associated with sodium concentration from the soil at Well-B2 are infrequent. However, the calculated MAR value is higher than the FAO permissible limits, suggesting that Well-B2 is unsuitable for irrigation use.

Furthermore, alterations to the groundwater physicochemical properties observed in this study are likely due to the effects of anthropogenic activities in agricultural areas. The excessive use of fertilisers and waterlogging practices for rice planting combined with the poor drainage conditions in the study area likely contributed to the degradation of the local groundwater quality [9-11]. Studies have shown that high amounts of salt ions in agricultural soils may be transported by irrigation water into the nearby groundwater through infiltration recharge [5,12]. Additionally, the high evapotranspiration rates in Brunei Darussalam are likely further to increase the salinity of irrigation water on the surface $[29,49]$. Tracer tests in the future could be utilised to differentiate groundwater flow and transport pathways at the site [50-52].

\subsection{Effects of Groundwater Pumping on Soil Quality}

Paddy soils near the existing groundwater pumping Well-B2 at site-2 (Figure 2b) were sampled and analysed for their physicochemical properties. Results were presented based on the sampling plots (Plots 1-3). Soil data (Figure 7) showed that all the analysed soil samples from site-2 are acidic, with $\mathrm{pH}$ values of less than 7. Based on the FAO pH range for paddy soils [53], 64\% of the analysed samples are considered too acidic $(\mathrm{pH}<5.5)$ and are unsuitable for rice planting. In particular, the soils at plot- 1 are notably more acidic than the soils at plots 2 and 3 . About $87 \%$ of the soils at plot- 1 are considered too acidic and unsuitable for rice planting compared to $53 \%$ at plots 2 and 3. Furthermore, results show that the samples from plot-1 have lower soil moisture than samples from plots 2 and 3. Lower soil pH and moisture at plot-1 could be explained by the effects of the nearby groundwater pumping well and lowering of groundwater levels in acid sulphate soils that contain pyrite and exposing them to an aerobic environment $[13,54]$.

The ash content in the soil samples ranges from $6 \%$ to $31 \%$, and the OM contents vary between $70 \%$ and $90 \%$. The soils' overall high organic matter content is likely due to waterlogging practices for rice planting [55]. The unique properties of flooded soils make rice different from any other crop. Due to prolonged flooding in rice fields, farmers can conserve soil organic matter and gain free nitrogen input from biological sources. Furthermore, agricultural practices such as tilling and ploughing are partly reflected in the plots, which may have helped incorporate some of the aboveground biomass (i.e., old rice plants) and led to the high soil OM content in the samples. On the other hand, the mineral matter and organic carbon from the peat layers present at the site can be mobilised during peat drainage and degradation [50].

High soil nutrients in agricultural areas are often linked to artificial fertilisers (NPK) and pesticides $[5,44]$. In the present study, the total nitrogen, phosphorous, and potassium concentrations in soil samples from plot-1 are notably lower than those from plots 2 and 3. The lower soil nutrients (total nitrogen, total phosphorous and total potassium) in plot- 1 could also be explained by the drainage effects of groundwater pumping from the nearby well, resulting in lower soil moisture as previously discussed and further hindering the transport and accumulation of nutrients in the soil. Furthermore, total magnesium concentrations are significantly higher in plot- 3 than plots 1 and 2 . In addition, no significant differences were found for the total calcium concentrations between the investigated plots. 


\subsection{Sustainability of Soil and Groundwater Resources in Agricultural Areas}

The productivity of soil and water resources is critical to the sustainability of irrigated agriculture. These resources, however, are limited and are threatened by salinity to varying degrees in the study area.

The geoelectrical resistivity study showed limited groundwater potentiality for abstraction and withdrawal for irrigation use in the study area. The poor water quality and groundwater yields from the existing groundwater wells (Well-B1 and Well-B2) further support these findings. In addition, the higher groundwater levels observed in the irrigated areas (sites 1 and 3) compared to the non-irrigated area (site 2) suggest that surface irrigation may be regarded as a significant source of recharge to the nearby groundwater, especially during the irrigation season. Future groundwater abstraction in the study area needs to consider local aquifer characteristics and long-term groundwater level and quality monitoring to avoid deterioration of groundwater levels due to overexploitation and alterations to the groundwater physicochemical properties. Our findings also show that soils near the groundwater pumping well were likely to be more acidic and thus unsuitable for rice farming. Therefore, the strategic placement of future irrigation wells is vital for the sustainability of soils in agricultural areas.

Extensive integrated soil and water monitoring strategies must be planned and implemented to achieve sustainable agricultural development. Flexible and sustainable irrigation techniques are required to tackle the problems of freshwater shortages in the study area. Furthermore, future groundwater irrigation wells need to consider local aquifer characteristics, groundwater flow paths and nutrient transport.

\section{Conclusions}

This study conducted soil and groundwater investigation at three rice cultivations sites in Brunei-Muara District, Brunei Darussalam. The geoelectrical resistivity method effectively delineates subsurface resistivity variations from which potential aquifer zones were deduced. The study area concluded three to four geoelectrical layers with resistivities ranging from 1 to $180 \Omega \mathrm{m}$ in the study area. A potential aquifer zone was detected at site- 3 at depths of about 40 to $60 \mathrm{~m}$ from the surface, with resistivities ranging from 10 to $150 \Omega \mathrm{m}$. However, this should be further confirmed by borehole drilling and hydraulic testing. Groundwater levels were shallower in irrigated fields compared to non-irrigated fields, suggesting that surface irrigation may be a significant source of recharge to the nearby groundwater, especially during the irrigation seasons. Water quality data indicate that the groundwater in the study area is unsuitable for irrigation use based on the high alkalinity and mineralisation of the water. Alterations to the groundwater physicochemical properties observed in this study are likely due to the effects of anthropogenic activities in agricultural areas. Soil data suggest that the analysed soils near the groundwater pumping well have lower $\mathrm{pH}$ values, moisture, and total nutrients, thus, unsuitable for farming. Therefore, the strategic placement of future irrigation wells is vital for the sustainability of soil resources in agricultural areas. The present study provides valuable insights to support robust decision-making to achieve sustainable agricultural production and development goals in the study area and other agricultural regions with similar geological conditions.

Supplementary Materials: The following supporting information can be downloaded at: https: / / www.mdpi.com/article/10.3390/su14031388/s1, Figure S1: Pseudo section and resistivity section for VES Profile 1 at Site-1; Figure S2: Interpretation of VES curve for stations 1-5 of Profile 1; Figure S3: Pseudo section and resistivity section for VES Profile 2 at Site-2; Figure S4: Interpretation of VES curve for stations 1-5 of Profile 2; Figure S5: Pseudo section and resistivity section for VES Profile 3 at Site-3; Figure S6: Interpretation of VES curve for stations 1-5 of Profile 3.

Author Contributions: Conceptualisation, S.L.A. and S.H.G.; methodology, S.L.A., A.A., R.S.S., S.M.J.; validation, S.L.A., A.A., R.S.S., S.M.J. and S.H.G.; formal analysis, S.L.A., A.A. and M.S.; investigation, S.L.A., A.A., R.S.S., S.M.J. and S.H.G.; resources, R.S.S., S.M.J., M.F.I., M.S., S.H.G.; data curation, S.L.A. and A.A.; writing-original draft preparation, S.L.A. and A.A.; writing-review and 
editing, R.S.S., S.M.J., M.S., S.H.G.; visualisation, S.L.A. and A.A.; supervision, R.S.S., S.M.J. and S.H.G.; project administration, S.H.G.; funding acquisition, M.S. and S.H.G. All authors have read and agreed to the published version of the manuscript.

Funding: This research was funded by UNIVERSITI BRUNEI DARUSSALAM, grant number UBD/RSCH/URC//RG(b)/2020/017.

Data Availability Statement: Not applicable.

Acknowledgments: The authors would like to thank the Ministry of Primary Resources and Tourism, Department of Agriculture and Agrifood, Brunei Darussalam, for the supplied data and for allowing the publication of this study. The authors would like to thank Preston GeoCEM Brunei for valuable discussions on the survey locations. The authors would like to express gratitude to Md Hafiezhullah DPH Ahmad, Md Hazwan Jamaluddin, Md Izwan Morni, Nur Ain Yusof, Siti Khadijah Annuar, Abdul Wafiy Ramle, and Amajida Roslim for their contribution as well as assistance in the field surveys. The authors thank Reto Britt from Eawag for trace element analysis of groundwater samples.

Conflicts of Interest: The authors declare no conflict of interest.

\section{References}

1. Siebert, S.; Döll, P. Quantifying blue and green virtual water contents in global crop production as well as potential production losses without irrigation. J. Hydro. 2010, 384, 198-217. [CrossRef]

2. Dalin, C.; Wada, Y.; Kastner, T.; Puma, M.J. Groundwater depletion embedded in international food trade. Nature 2017, 7647, 700-704. [CrossRef]

3. Giordano, M.; Villholth, K.G. The Agricultural Groundwater Revolution: Opportunities and Threats to Development; International Water Management Institute Colombo: Battaramulla, Sri Lanka, 2007; p. 420.

4. Gödeke, S.H.; Malik, O.A.; Lai, D.T.C.; Bretzler, A.; Schirmer, M.; Mansor, N.H. Water quality investigation in Brunei Darussalam: Investigation of the influence of climate change. Environ. Earth Sci. 2020, 79, 18. [CrossRef]

5. Kachi, N.; Kachi, S.; Bousnoubra, H. Effects of irrigated agriculture on water and soil quality (case perimeter Guelma, Algeria). Soil Water Res. 2016, 1, 97-104. [CrossRef]

6. Stigter, T.Y.; Ooijen, S.P.J.V.; Post, V.E.A.; Appelo, C.A.J.; Dill, A.M.M.C. A hydrogeological and hydrochemical explanation of the groundwater composition under irrigated land in a Mediterranean environment, Algarve. Portugal. J. Hydro. 1998, 208, 262-279. [CrossRef]

7. Zhu, D.; Ryan, M.C.; Sun, B. The influence of irrigation and Wuliangsuhai Lake on groundwater quality in eastern Hetao Basin, Inner Mongolia, China. Hydrogeol. J. 2014, 22, 1101-1114. [CrossRef]

8. Gödeke, S.H. Simulation of groundwater mounding at a West Australian mine site. Environ. Earth Sci. 2011, 64, 1363-1373. [CrossRef]

9. Khalil, M.M.; Abotalib, A.Z.; Farag, M.H.; Rabei, M.; Abdelhady, A.A.; Pichler, T. Poor drainage-induced waterlogging in Saharan groundwater-irrigated lands: Integration of geospatial, geophysical and hydrogeological techniques. Catena 2021, $207,105615$. [CrossRef]

10. Tewabe, D.; Dessie, M.; Asmamaw, D.K.; Tamiru, E.; Adgo, E.; Nyssen, J.; Walraevens, K.; Cornelis, W.M. Comparative analysis of groundwater conditions on rain-fed and irrigated agriculture in the upper Blue Nile basin, Ethiopia. J. Hydro. Reg. Stud. 2021, 37, 100916. [CrossRef]

11. Singh, G.; Lal, K. Review and Case Studies on Biodrainage: An Alternative Drainage System to Manage Waterlogging and Salinity. Irrig. Drain. 2018, 67, 51-64. [CrossRef]

12. Jai, H.; Qian, H.; Zheng, L.; Feng, W.; Wang, H.; Gao, Y. Alterations of groundwater chemistry due to modern water transfer for irrigation over decades. Sci. Total Environ. 2020, 717, 137170. [CrossRef]

13. Grealish, G.J.; Fitzpatrick, R.W. Acid sulphate soil characterisation in Negara Brunei Darussalam: A case study to inform management decisions. Soil Use Manag. 2013, 29, 432-444. [CrossRef]

14. Syed, A.; Sarwar, G.; Shah, S.H.; Muhammad, S. Soil Salinity Research in 21st Century in Pakistan: Its Impact on Availability of Plant Nutrients, Growth and Yield of Crops. Commun. Soil Sci. Plant Anal. 2019, 52, 183-200. [CrossRef]

15. Mogaji, K.A.; Olayanju, G.M.; Oladapo, M.I. Geophysical evaluation of rock type impact on aquifer characterisation in the basement complex areas of Ondo state, Southern Nigeria: Geo-electric assessment and Geographic Information Systems (GIS) approach. Int. J. Wat. Res. Environ. Eng. 2011, 3, 77-86.

16. Riwayat, A.I.; Ahmad Nazri, M.A.; Zainul, M.H. Application of Electrical Resistivity Method (ERM) in Groundwater Exploration. J. Phys. Conf. Ser. 2018, 995, 012094. [CrossRef]

17. Halihan, T.; Albano, J.; Comfort, S.D.; Zlotnik, V.A. Electrical resistivity imaging of a permanganate injection during in situ treatment of RDX-contaminated groundwater. Ground Water Monit. Remediat. 2012, 32, 43-52. [CrossRef]

18. Vogelgesang, J.A.; Holt, N.; Schilling, K.E.; Gannon, M.; Tassier-Surine, S. Using high-resolution electrical resistivity to estimate hydraulic conductivity and improve characterization of alluvial aquifers. J. Hydro. 2020, 580, 123992. [CrossRef] 
19. Sikandar, P.; Christen, E.W.; Stein, T.M. Vertical electrical sounding (VES) for salinity assessment of water-bearing formations. Irrig. Drain. 2017, 66, 252-262. [CrossRef]

20. Keller, G.V.; Frischknecht, F.C. Electrical Methods in Geophysical Prospecting; Pergamon Pr.: Oxford, UK, $1981 ;$ p. 526.

21. Samouëlian, A.; Cousin, I.; Tabbagh, A.; Bruand, A.; Richard, G. Electrical resistivity survey in soil science: A review. Soil Tillage Res. 2005, 83, 173-193. [CrossRef]

22. Azffri, S.L.; Ali Ahmad, A.S.; Ibrahim, M.F.; Khalid, A.A.; Murphy, J.J.; Gödeke, S.H. Groundwater exploration through 2D electrical resistivity tomography in Labi agricultural site, Belait District, Brunei Darussalam. Thai Geos. J. 2022, accepted.

23. Brunei Darussalam Meteorological Department. Climate. Available online: www.bruneiweather.com.bn (accessed on 15 October 2021).

24. Hall, R.; Nichols, G. Cenozoic sedimentation and tectonics in Borneo: Climatic influences on orogenesis. In Sediment Flux to Basins: Causes, Controls and Consequences; Jones, S.J., Frostick, L., Eds.; Geological Society, London, Special Publications: London, UK, 2002; pp. 5-22.

25. Sandal, S.T. The Geology and Hydrocarbon Resources of Negara Brunei Darussalam; Brunei Shell Petroleum Company: Bandar Seri Begawan, Brunei, 1996; p. 243.

26. Visvanathan, Y.; Gödeke, S.H. Study of ground investigation data along the Brunei Temburong Bridge alignment. Q. J. Eng. Geol. Hydrogeol. 2021, qjegh2021-002. [CrossRef]

27. Chuan, G.K. Hydrological Characteristics and Water Resources. Singap. J. Trop. Geog. 1992, 13, 1. [CrossRef]

28. Food and Agriculture Organisation of the United Nations. AQUASTAT Country Profile—Brunei Darussalam; FAO: Rome, Italy, 2011; p. 8.

29. Moeck, C.; Grech-Cumbo, N.; Podgorski, J.; Bretzler, A.; Gurdak, J.J.; Berg, M.; Schirmer, M. A global-scale dataset of direct natural groundwater recharge rates: A review of variables, processes and relationships. Sci. Total Environ. 2020, 717, 137042. [CrossRef] [PubMed]

30. Azhar, A.S.; Abdul Latiff, A.H.; Lim, L.H.; Gödeke, S.H. Groundwater investigation of a coastal aquifer in Brunei Darussalam using seismic refraction. Environ. Earth Sci. 2019, 78, 220. [CrossRef]

31. Hong, W.J.; Shamsuddin, N.; Abas, E.; Apong, R.A.; Masri, Z.; Suhaimi, H.; Gödeke, S.H.; Noh, M.N.A. Water Quality Monitoring with Arduino Based Sensors. Environments 2021, 8, 6. [CrossRef]

32. Department of Agriculture and Agrifood. Brunei Darussalam Agriculture and Agrifood Statistics in Brief. 2020. Available online: http:/ / www.agriculture.gov.bn/SiteCollectionDocuments/Statistik/Agriculture \%20and\%20Agrifood $\% 20$ Statistic\%20 2020.pdf (accessed on 15 October 2021).

33. Zin, K.P.; Lim, L.H.; Holige Mallikarjunaiah, T.; Bandara, J.M.R.S. Chemical properties and phosphorus fractions in profiles of acid sulfate soils of major rice-growing areas in Brunei Darussalam. Geoderma Reg. 2015, 6, 22-30. [CrossRef]

34. Wasil, W. Agri Dept to Pilot Irrigation System, Seeks to Boost Rice Production. Available online: https://thescoop.co/2019/02/ 13/3-9m-imang-dam-upgrade-to-improve-irrigation-supply-boost-rice-output/ (accessed on 15 October 2021).

35. Telford, W.M.; Geldart, L.P.; Sheriff, R.E. Applied Geophysics; Cambridge University Press: Cambridge, UK, 1990 ; p. 770.

36. Binley, A. Tools and techniques: Electrical methods. In Treatise on Geophysics, 2nd ed.; Gerald, S., Ed.; Elsevier: Oxford, UK, 2015; Volume 11, pp. 233-259. [CrossRef]

37. Szalai, S.; Novák, A.; Szarka, L. Depth of Investigation and Vertical Resolution of Surface Geoelectric Arrays. J. Environ. Eng. Geophys. 2009, 14, 15-23. [CrossRef]

38. Bobachev, C. IPI2Win A Windows Software for an Automatic Interpretation of Resistivity Sounding Data. Ph.D. Thesis, Moscow State University, Moscow, Russia, 2002; p. 320.

39. Ibrahim, M.F.; Department of Agriculture and Agrifood, Bandar Seri Begawan, Brunei Darussalam. Personal communication, 2021.

40. Richards, L.A. Diagnosis and Improvement of Saline and Alkali Soils; Agricultural handbook 60; USDA and IBH Pub. Coy Ltd.: New Delhi, India, 1954; pp. 98-99.

41. Baird, R.; Bridgewater, L. Standard Methods for the Examination of Water and Wastewater, 23rd ed.; American Public Health Association: Washington, DC, USA, 2017.

42. Parkhurst, D.L.; Appelo, C.A.J. Description of Input and Examples for PHREEQC Version 3: A Computer Program for Speciation, Batch-Reaction, One-Dimensional Transport, Inverse Geochemical Calculations, TECHNIQUES and Methods; US Geological Survey: Reston, VA, USA, 2013. [CrossRef]

43. Ayers, R.S.; Westcot, D.W. Water Quality for Agriculture: Irrigation and Drainage; FAO: Rome, Italy, $1985 ;$ pp. 1-117.

44. Gebremeskel, G.; Gebremicael, T.G.; Kifle, M.; Meresa, E.; Gebremedhin, T.; Girmay, A. Salinization pattern and its spatial distribution in the irrigated agriculture of Northern Ethiopia: An intergrated approach of quantitative and spatial analysis. Agric. Water Manag. 2018, 206, 147-157. [CrossRef]

45. Singh, K.K.; Tewari, G.; Kumar, S. Evaluation of Groundwater Quality for Suitability of Irrigation Purposes: A Case Study in the Udham Singh Nagar. Uttarakhand. J. Chem. 2020, 6924026, 15. [CrossRef]

46. Allen, S.E. Chemical Analysis of Ecological Materials, 2nd ed.; Blackwell Scientific Publications: Oxford, UK, 1989.

47. Bewick, V.; Cheek, L.; Ball, J. Statistics review 9: One-way analysis of variance. Crit. Care 2004, 8, 130. [CrossRef]

48. R Development Core Team. R: A Language and Environment for Statistical Computing; R Foundation for Statistical Computing: Vienna, Austria, 2012; ISBN 3-900051-07-0. 
49. Trabucco, A.; Zomer, R.J. Global High-Resolution Soil-Water Balance. Figshare, Dataset. 2019. Available online: https:/ figshare. com/articles/dataset/Global_High-Resolution_Soil-Water_Balance/7707605/3 (accessed on 1 November 2021).

50. Suhip, M.A.A.B.H.; Gödeke, S.H.; Cobb, A.R.; Sukri, R.S. Seismic refraction study, single well test and physical core analysis of anthropogenic degraded Peat at the Badas Peat Dome, Brunei Darussalam. Eng. Geol. 2020, 273, 105689. [CrossRef]

51. Gödeke, S.; Richnow, H.H.; Weiß, H.; Fischer, A.; Borsdorf, H.; Schirmer, M. Multispecies-Reactive Tracer Test for the implementation of enhanced in situ bioremediation at a BTEX contaminated megasite. Contam. Hydrol. 2006, 87, 211-236. [CrossRef] [PubMed]

52. Gödeke, S.; Geistlinger, H.; Fischer, A.; Richnow, H.H.; Wachter, T.; Schirmer, M. Simulation of a reactive tracer experiment using stochastic hydraulic conductivity fields. Environ. Geol. 2008, 55, 1255-1261. [CrossRef]

53. Roy, R.N.; Finck, A.; Blair, G.J.; Tandon, H.L.S. Plant Nutrition for Food Security: A Guide for Integrated Nutrient Management; FAO: Rome, Italy, 2006; p. 366.

54. Marshall, D.J.; Abdelhady, A.A.; Wah, D.T.T.; Mustapha, N.; Gödeke, S.H.; De Silva, L.C.; Hall-Spencer, J.M. Biomonitoring acidification using marine gastropods. Sci. Total Environ. 2019, 692, 833-843. [CrossRef] [PubMed]

55. Hu, Y.; Lu, Y.H.; Edmonds, J.; Liu, C.; Zhang, Q.; Zheng, C. Irrigation alters source-composition characteristics of groundwater dissolved organic matter in a large arid river basin, Northwestern China. Sci. Total Environ. 2021, 767, 144372. [CrossRef] [PubMed] 